Психология. Журнал Высшей школы экономики,

2017. T. 14. № 4. C. 607-625. DOI: 10.17323/1813-8918-2017-4-607-625

\title{
ПОЛИФОНИЧЕСКАЯ ПЕРСОНОЛОГИЯ В.А. ЛЕФЕВРА И ФУНДАМЕНТАЛЬНОЕ РАЗВИТИЕ РЕФЛЕКСИВНЫХ НАУК О ЧЕЛОВЕКЕ И ВСЕЛЕННОЙ
}

\author{
И.Н. СЕMЕHOB
}

${ }^{2}$ Национальный исследовательский университет «Высиая икола экономики», 101000, Россия, Москва, ул. Мясницкая, д. 20

\section{Резюме}

Одним из фундаментальных достижений человекознания на рубеже XX-XXI столетий служит «Рефлексивная психология Владимира Лефевра» (Wheeler, 1990). Она является результатом междисциплинарного синтеза ряда возникших во второй половине XX в. рефлексивных наук: логики, семиотики, психологии, конфликтологии, этики, менеджмента, политологии, системотехники, кибернетики, физики, математики, космологии. В развитие каждой из них крупный российско-американский ученый В.А. Лефевр внес свой вклад. В.А. Лефевру свойствены ренессансный диапазон исследовательских интересов, феноменальная креативность, энциклопедизм профессиональной деятельности. Исследовательской целью статьи является анализ жизненного пути В.А. Лефевра и его творческих достижений в области междисциплинарного изучения такой сложной психологической реальности, как рефлексия. Впервые предложена персонологическая периодизация жизнедеятельности В.А. Лефевра, охарактеризовано развитие его личности на трех ключевых периодах творчества (советском, американском, трансатлантическом), проведен науковедческий анализ научных достижений. Показана конструктивность системно-междисциплинарного подхода В.А. Лефевра к исследованию и освоению рефлексивных процессов в контексте современного развития науки и общества. Новизна излагаемых в статье результатов исследования жизнетворчества В.А. Лефевра определяется системной методологией его рефлексивно-науковедческого изучения, согласно принципу дополнительности. Этот принцип реализуется посредством взаимодействия персонологического подхода к характеристике творческой личности В.А. Лефевра и науковедческого подхода к анализу осуществляемой им инновационной научной деятельности в современном социокультурном контексте развития науки и общества. В итоге показано фундаментальное значение междисциплинарных трудов В.А. Лефевра для изучения рефлексии в масштабах человекознания и космологии.

Ключевые слова: философия, науковедение, методология, логика, система, персонология, психология, конфликтология, этика, космология, рефлексия, деятельность, управление, творчество.

Исследование осуществлено в рамках Программы «Научный фонд НИУ ВШЭ» проект № 12-01-0120. 


\section{Роль В.А. Лефевра в научном изучении рефлексии}

Одной из конструктивных новаций в сфере социально-гуманитарного знания последней трети ХХ в. является выделение - в качестве особой междисциплинарной области инновационного научного изучения рефлексии в методологии, логике, лингвистике, психологии, социологии, культурологии. Новаторская роль в этом принадлежит выдающемуся российско-американскому философу и ученому Владимиру Александровичу Лефевру (Лефевр, 1965, 1971, 1991, 2003a, 20036, 2005; Wheeler, 1990; Lefebvre, 2006).

Известно, что хотя феноменология рефлексии восходит к Античности (Сократ, Платон, Аристотель, Плотин, Августин), а рельефно она обозначилась при переходе от Средневековья (Фома Аквинский) к Возрождению (Монтень, Николай Кузанский), ее философское осмысление и категоризация приходятся на Новое время (Декарт, Локк, Лейбниц, Фихте, Гегель) и Новейшую эпоху (Дьюи, Гуссерль, Сартр). Однако переход от философствования о рефлексии к ее собственно научному изучению требует в качестве своих необходимых предпосылок определенного методологического базиса и конструктивного исследовательского подхода к формированию предмета и разработке методов соответствуюших научных изысканий: конкретно-эмпирических, абстрактно-онтологических, операционально-исследовательских, модельно-экспериментальных, проектно-социотехнических, организационно-социокультурных, прагматико-технологических и т.п.
В создании всех этих конструктивных предпосылок собственно научного (в том числе логико-математического и психолого-этического) изучения рефлексии, а главное - в его концептуально-процедурной реализации и эффективном социально-праксиологическом освоении - фундаментальная роль принадлежит крупному российскоамериканскому ученому рубежа XXXXI вв. B.A. Лефевру. Сотрудничая с системными методологами (Г.П. Шедровицкий, Н.Г. Алексеев, И.С. Ладенко, В.Н. Садовский, Э.Г. Юдин) в процессе разработки системодеятельностной методологии (см.: Семенов, 2014), В.А. Лефевр выдвинул и разработал фундаментальные инновационные идеи, во многом определившие современную ему философско-научную трактовку рефлексии. При этом в процессе оригинальной реализации своей концепции рефлексии В.А. Лефевр создал целое научное направление ее логико-психологических и шире социотехнических и междисциплинарных исследований (В.Е. Лепский, Г.Л. Смолян, П.В. Баранов, А.Ф. Трудолюбов, В.И. Дубовская и мн. др.). Рассмотрим эволюцию жизненного пути В.А. Лефевра и развитие созданного им направления научного изучения рефлексии.

\section{Основные этапы} жизнедеятельности В.А. Лефевра

Прежде чем обобщенно охарактеризовать научные достижения В.А. Лефевра, дифференцируем основные этапы развития его оригинальной личности и плодотворной научной деятельности.

Первыц эman. Владимир Александрович родился в 1936 г. в 
Ленинграде (ныне Санкт-Петербург), во время войны ребенком пережил блокаду города немецкими войсками, что принесло ему экзистенциальные страдания, но и закалило его волю и характер.

Bторой этап - рубеж 1940-1950-х гг. Переехав с родителями в Москву, он получил школьное образование и начал свою трудовую деятельность.

Tретийэтап - рубеж 1950-1960-х гг. Совмещая работу с учебой, он заочно окончил в 1963 г. физико-математический факультет Московского государственного университета имени М.В. Ломоносова и стал интенсивно вести научно-исследовательскую деятельность в оборонном ведомстве по прикладным вопросам военной кибернетики. При этом с конца 1950-х и до середины 1960-х гг. В.А. Лефевр активно участвовал в творческой деятельности организованного крупным философом и логиком А.А. Зиновьевым логического кружка, который вскоре трансформировался под руководством его ученика, крупного системного методолога Г.П. Шедровицкого, в Московский методологический кружок (ММК). В ММК В.А. Лефевр особенно тесно сотрудничал с Г.П. Щедровицким и Э.Г. Юдиным (см. о них: Семенов, 2014, с. 101-104, 127-167) в изучении системно-методологических проблем философии, логики, кибернетики и семиотики. Так, например, развивая начатую Г.П. Педровицким и Н.Г. Алексеевым разработку в MМK проблем организации мыслительной деятельности, В.А. Лефевр предложил свою трактовку строения способов решения задач. При этом он в составе команды единомышленников по ММК участвовал в работе съездов психологов (Лефевр, 1963) и конференций философов (Лефевр, 1965), где выступал с оригинальными докладами. Именно на стыке взаимодействия фундаментальных методологических поисков в ММК (см.: Семенов, 2014, с. 101-104) и военно-прикладных разработок по инженерной психологии и эргономике В.А. Лефевр начал оригинальные изыскания в области научно-кибернетического изучения рефлексивных процессов.

Четвертый этап - рубеж 1960 1970-х гг. Работая на закрытых оборонных предприятиях по проблемам военной кибернетики, В.А. Лефевр стал самостоятельно исследовать «логику рефлексивных игр» (Лефевр, 1965), предложив оригинальный логико-математический аппарат для описания мыслительных процессов конфликтного противоборства.

В это же время он организует творческую неформальную группу единомышленников (В.Е. Лепский, Г.Л. Смолян, П.В. Баранов, А.Ф. Трудолюбов) по психолого-кибернетическому изучению рефлексии (Лефевр и др., 1969) при поддержке системотехника Д.А. Поспелова, психолога В.Н. Путкина и системного методолога из ММК В.Н. Садовского. При этом В.А. Лефевр разрабатывает логико-математический аппарат (Лефевр, 1971) для формального описания рефлексивных процессов при принятии рештений, с помощью которого выстраивает «Алгебру конфликта» (Лефевр, Смолян, 1968). На этом этапе кибернетический подход В.А. Лефевра к «системам с рефлексией» получает признание в научных кругах: он публикуется в ряде академических изданий 
(Лефевр и др., 1965) и в первом выпуске авторитетного философскометодологического Ежегодника АН СССР «Системные исследования» (Лефевр, 1969), а также приглашается на престижную научную работу (не имея ученой степени) в Центральный экономико-математический институт (ЦЭМИ) в системе AH CCCP.

Пятый эman. В 1971 г. В.А. Лефевр - при поддержке декана психологического факультета МГУ, академика АПН СССР А.Н. Леонтьева и заведуюшего кафедрой инженерной психологии МГУ профессора В.П. Зинченко - успешно зашищает первую в СССР кандидатскую диссертацию по инженерно-психологическим аспектам рефлексии. В развитие этого психолого-кибернетического подхода В.А. Лефевр разрабатывает «психографику», позволяющую изображать рефлексивное взаимодействие субъектов в конфликтном противоборстве. В это время он организует в ЦЭМИ логико-методологический семинар с разработкой инновационных проблем методологии, математической логики, кибернетики, семиотики, психографики. На этом междисциплинарном семинаре выступали с докладами как маститые мэтры (Д.А. Поспелов, В.Н. Пушкин, В.Н. Садовский, Ю.А. Шрейдер), так и молодые ученые (В.Е. Лепский, Б.В. Сазонов, И.Н. Семенов, Г.л. Смолян и др.). Определенное гражданское мужество потребовалось В.А. Лефевру, чтобы пригласить опального Г.П. Щедровицкого (подписавшего в 1968 г. коллективное письмо интеллигенции с протестом против ввода советских войск в
Чехословакию) выступить на этом семинаре с серией докладов по системодеятельностной методологии. Предоставление Г.П. Шедровицкому с учениками (в числе которых был в то время и я) легальной трибуны фактически означало, что В.А. Лефевр, уже оставивший к тому времени ММК, способствовал в ту подцензурную «застойную» эпоху неформальной интеграции в научное сообщество инновационных идей ММК. На базе своего семинара в ЦЭМИ В.А. Лефевр создает научную школу по логико-математическому изучению экономико-кибернетических проблем управления, в том числе на материале логики и психологии рефлексивных игр и принятия решений. Инновационная эффективность фундаментально-психологических и военно-прикладных трудов В.А. Лефевра позволяла в имитационных ситуациях конфликтного противоборства переигрывать противника, следующего традиционной - для западной военной кибернетики - стратегии, базирующейся на классической теории игр.

IUecmoй эman. В 1974 г. В.А. Лефевр переехал с семьей в США, начал адаптироваться к новой жизни и преподавать в качестве профессора в американских университетах (в том числе в Калифорнийском), где стал разрабатывать логико-психологические и кибернетико-математические проблемы организации ментальности человека и социума с учетом изучения роли рефлексивных процессов в системах управления.

Седъмой этап - рубеж 1970 1980-х гг. Продолжая в США преподавать в университетах, он сотрудни- 
чает с гражданскими и военными корпорациями по проблемам изучения рефлексивного управления и разработке его этико-психологических приложений в социальной практике. Известность В.А. Лефевру в научных и обшественных кругах США принесла книга «Алгебра совести» (Lefebvre, 1982), где им была развита и обоснована теория двух этических систем. Представители одной из них воспринимают компромисс между добром и злом как зло, а адепты другой - как добро: для первой системы характерен запрет зла (например, «не лги»), для второй призыв к добру («будь правдив»). Причем первые имеют тенденцию к компромиссу с людьми: к терпимости, толерантности и тем самым - к разрешению конфликтов, а вторые стремятся к борьбе до победы с конкретными индивидами - к эскалации конфликтов.

Восьмой этап - вторая половина 1980-х гг. В.А. Лефевр углубляет этико-психологические аспекты своего методологического подхода к человеку, разрабатывая философскоантропологические проблемы его кибернетического изучения. В результате он готовит к изданию обобщающую его изыскания книгу «Формула человека: Контуры фундаментальной психологии» (Лефевр, 1991). Здесь он в широком диапазоне логико-математически изучает рефлексивность психики субъекта: от свободы воли через категоризацию стимулов до принятия решений, основанных на вере, а также обосновывает свою оригинальную интерпретацию золотого сечения, музыкальных и элитных интервалов, этического статуса суб́ьекта.
Девятый этап. В начале 1990-х гг. начинается «трансатлантический» период научной деятельности В.А. Лефевра, он стал вновь публиковаться в российской научной печати и посещать с лекциями свою родину. При этом он почти ежегодно пересекает Атлантический океан в целях обеспечения международного сотрудничества энтузиастов рефлексивного управления. В.А. Лефевр оказывает поддержку своим ученикам в СССР и в новой России, организуя в 1994 г. с В.Е. Лепским на базе Института психологии РАН первую в новой России научно-практическую конференцию по рефлексивному управлению в контексте менеджмента и эргономики (см.: Семенов, 2014, c. 109-112, 127-135, 177-182). Это оказалось возможным при поддержке лидеров российской гуманитаристики: директора Института психологии РАН члена-корреспондента АН СССР А.В. Брушлинского, члена-корреспондента РАО Н.Г. Алексеева, академиков РАО В.П. Зинченко и В.М. Мунипова, президента PAO А.В. Петровского, вице-президента PAO В.В. Давыдова, главного редактора журнала «Вопросы философии» академика РАН В.А. Лекторского, главного редактора журнала «Человек» при Президиуме РАН члена-корреспондента РАН Б.Г. Юдина, академика РАО И.С. Ладенко и др. Данный междисциплинарный форум возродил в условиях новой российской действительности возникшую в начале 1980-х гг. традицию философских, психологических и педагогических (Пономарев и др., 1988) конференций по проблематике рефлексии. Позднее при поддержке В.А. Лефевра его соратник В.Е. Лепский организует 
двухгодичные симпозиумы по междисциплинарному изучению рефлексивного управления. При этом в России начинается систематическое переиздание классических работ В.А. Лефевра по логике и психологии рефлексивных игр (Лефевр, 1990, 1991), а также публикация переводов его фундаментальных трудов американского периода. На родине он избирается академиком Российской академии естественных наук (PAEH).

Десятый эman. В 1990-е гг. В.А. Лефевр обосновывает концепцию «Рефлексивной психологии Владимира Лефевра» (Lefebvre, 1990 - см.: Wheeler, 1990) и позднее расширяет онтологический масштаб философско-кибернетической трактовки человека, включая его рефлексивнопсихологический анализ в космологический контекст естественно-научного изучения Вселенной. Результаты этого анализа были обобшены в 1996 г. в его фундаментальном труде «Космический субъект» (Лефевр, 2005). Стремясь вписать сознающего и рефлексирующего субъекта в физическую картину мира, В.А. Лефевр впервые в психологии трактует человека как «неотъемлемую часть Вселенной, порождение и участника космологического процесса». Смысл существования космического субъекта заключается в удлинении цепочки последовательных рефлексивных актов, надстраивающихся друг над другом. В физикалистской парадигме, с точки зрения термодинамической модели субъекта, это означает его стремление стать «вечным двигателем». Отсюда задачей «магнито-плазменных космических субъектов» становится борьба с «тепловой смертью» Вселенной посредством ее «большой коррекции». Этой деятельностью космических субъектов В.А. Лефевр объясняет наблюдаемую современной астрономией активность «квазаров» и «радиогалактик». Выстраиваемая В.А. Лефевром рефлексивно-субъектная картина мира конкретизируется им через конструирование ряда оригинальных моделей и концептуальных схем (см.: Семенов, 2014, c. 204-237), описывающих логикоматематическими и рефлексивнопсихографическими методами взаимодействие философской, этической, психологической, кибернетической, физической, космологической парадигм в трактовке человека и космоса. Эти достижения В.А. Лефевра знаменуют собой расширение традиционной для ММК системодеятельностной парадигмы (Щедровицкий и др., 1993), дополняя углубляющими ее реализацию в изучении рефлексии естественнонаучной и социотехнической парадигматиками.

Методологически анализируя разрешающую способность построенной им формальной модели субъекта (обладающего совестью и способного к рефлексии), В.А. Лефевр обнаружил, что эта модель, помимо этико-психологических феноменов, описывает также своеобразный термодинамический процесс, который представляет собой последовательность «тепловых машин». Отсюда, по В.А. Лефевру, сознание человека представляет собой «вид существования термодинамических характеристик нейронных сетей, производящих вычислительные процессы», что актуально в контексте современной 
синергетики (В.И. Аршинов, В.Е. Лепский) и нейронауки (Н.П. Бехтерева, В.А. Ключарев, А.Р. Лурия, Е.Н. Соколов). На основе термодинамической модели субъекта он выводит классические психофизические законы Фехнера и Стивенса и ряд явлений в психологических экспериментах пропорции «золотого сечения», а также объясняет сущность медитации и природу музыкального строя (в виде натуральных интервалов). Исходя из онтологического постулата, что его формальная модель описывает не только реального человека, но также любого субъекта, который может существовать во Вселенной, В.А. Лефевр обосновывает предположение, согласно которому материальной основой современных космических существ могут быть магнитоплазменные образования, родственные магнитосферам звезд и планет, - потоки плазмы, структурированные магнитным полем. На этом основании и с учетом того, что в основе совести и натуральных музыкальных интервалов лежат сходные алгебраические структуры, В.А. Лефевр делает важный для астрономической практики вывод, что с целью обнаружения внеземных разумных Космических субъектов следует искать музыкальные структуры в потоках сигналов, регистрируемых из космоса. В этом контексте особое значение приобретает реинтерпретация с позиций рефлексивной психологии В.А. Лефевра фундаментальных достижений Б.М. Теплова (см.: Семенов, 2016) по изучению музыкальных переживаний и « Психологии музыкальных способностей» (Теплов, 1947), изданной в ряде зарубежных стран.
Oдиннадияатый этап. В 2000-е гг. В.А. Лефевр интегрирует теоретические результаты свонх многообразных полидисциплинарных исследований в обобщающих книгах (Лефевр, 2003б, 2009; Lefebvre, 2006). Цель этой теории - предсказывать индивидуальный выбор субъекта, входящего в группу, и исследовать возможности рефлексивного управления этим выбором. Связь интересов социальной группы с индивидуальными интересами субъектов координируется фундаментальным принципом «запрета эгоизма», согласно которому каждый субъект, преследуя свои личные цели, не может наносить ущерб группе как целому. Методологически этот принцип столь же важен для теории рефлексивных игр, как и принцип «гарантированного результата» для классической теории игр. В «Лекциях» (Лефевр, 2009) приводится множество конкретных примеров прикладного рефлексивного анализа разнообразных ситуаций из области конфликтного противоборства, межличностных коммуникаций, этики поведения, а также из сферы юриспруденции, политики, международных и военных отношений.

Параллельно научной деятельности В.А. Лефевр и В.Е. Лепский раз в два года организуют в Москве на базе Института философии РАН симпозиум с участием ведущих ученых разных стран по изучению проблематики стратегической роли рефлексии в социальных системах и издание международного междисциплинарного научно-практического журнала «Рефлексивные процессы и управление» (Петровский, 2001; Semyonov, 2002) 
Двенадиатый этап. В 2010-е гг. В.А. Лефевр, продолжая преподавать в Калифорнийской университете в Ирвайне, сотрудничает с мозговым центром CADS, вносит свою весомую лепту в борьбу с терроризмом. При этом он обобщает свои междисциплинарные исследования, публикует фундаментальные труды и продолжает разработку новых философско-математических и психологокосмологических проблем современного естествознания, в том числе по проблематике психологии рефлексии. Об этом свидетельствует недавний рефлексивно-сотворческий диалог в виде научно-персонологического интервью, взятого у В.А. Лефевра B.A. Петровским (Петровский, 2013).

\section{Три ключевых периода научного творчества В.А. Лефевра}

Научно-творческая деятельность В.А. Лефевра с чисто внешней социально-экологической и культурно-хронологической - стороны в целях целостного охвата и объемного рефлексивно-методологического анализа целесообразно дифференцировать на три основных периода, условно говоря: «советский», «американский» и «трансатлантический». Охарактеризуем суть каждого периода подробнее.

Первый «советский» период до 1974 г. - это время формирования творческой индивидуальности В.А. Лефевра в процессе его школьной и университетской учебы и становления ученого-новатора в области фундаментальной науки (от математики и физики через кибернетику и логику до философии и психологии) и в сфере методологии социотехнических наук. Этот период завершился созданием В.А. Лефевром оригинальной концепции рефлексии и методов (Лефевр, 1971), реализующих ее научное изучение посредством инновационного логико-математического аппарата «рефлексивных игр», что было обобщено им в 1971 г. в первой в нашей стране кандидатской диссертации, посвященной инженерно-психологическому исследованию рефлексии в контексте проектирования и управления.

Второй «американский» период до 1990 г. - время углубленной конкретизации и дифференциации этой концепции в целях развития операционно-верифицирующих ее методов применительно к новым предметным областям, а главное - их рефлексивно-праксиологическое освоение (Lefebvre, 1982; Wheeler, 1990) аксиолого-технологическими средствами новых прагматических сфер (политики, экономики, менеджмента и т.п.).

В третий «трансатлантический» период от 1991 г. и до настоящего времени В.А. Лефевр работает в университетах США и часто приезжает в новую Россию. При этом он ведет междисциплинарные и прагматические исследования рефлексии в различных направлениях, актуальных научно и практически, а главное концептуализируя и обобщая их результаты в фундаментальном учении о рефлексии и организуя вместе с В.Е. Лепским (см.: Лефевр и др., 2009) их международное обсуждение, в том числе в сборниках материалов международных симпозиумов «Рефлексивные процессы и управление» 1994-2017 гг. и в 
выпусках одноименного журнала в 2001-2017 гг

Плодотворно влияние идей и методов В.А. Лефевра всех трех периодов не только на парадигмально родственные ему естественнонаучные и социотехнические варианты отечественных концепций рефлексии (Н.Г. Алексеева, О.И. Генисаретского, И.С. Ладенко, В.Е. Лепского, М.А. Розова), реализуемые на основе соответствующей логикоматематической верификации в проектной практике рефлексивного управления (В.Е. Лепский, Г.Л. Смолян, Г.Н. Солнцева, П.В. Баранов и др.), но и на содержательно иные концепции психологии рефлексии (см.: Петровский, 2001; Пономарев и др., 1988; Семенов, 2009, 2014; Semenov, 2013).

\section{Взаимодействие В.А. Лефевра с другими научными школами изучения рефлексии}

Важно подчеркнуть, что под воздействием идей В.А. Лефевра различные научные школы (Семенов, 2009) исследования рефлексии развивались параллельно созданному им направлению, но в парадигмальных рамках иных концептуальнометодологических подходов (Semenov, 2013): проектно-деятельностного (Н.Г. Алексеев, О.И. Генисаретский, В.Я. Дубровский, Б.В. Сазонов, Г.П. Педровицкий), организационноигрового (Н.Г. Алексеев, О.С. Анисимов, Ю.В. Громыко, П.Г. Щедровицкий), интеллектуально-деятельностного (В.В. Давыдов, А.З. Зак, А.В. Захарова, В.В. Рубцов, В.И. Слободчиков), гуманитарно-культурологического (Н.И. Непомнящая,
В.М. Розин, И.Н. Семенов, С.ІО. Степанов).

Необходимо подчеркнуть эвристическую роль В.А. Лефевра в процессе взаимодействия в ММК с его лидером Г.П. Шедровицким и с другими участниками, в особенности с В.Н. Садовским и Э.Г. Юдиным будущими создателями отечественной системной методологии науки. Во время творческого сотрудничества В.А. Лефевра с ними на рубеже 1960-1970-х гг. были введены и концептуализированы такие ставшие классическими в системно-деятельностной методологии ММК инновации, как дифференциация «естественного» и «искусственного» в науке, «конфигурирование» в проектировании, «таблоизация сознания», «рефлексивность управления». Два последних конструкта оказали определяющую роль в фундаментальной трактовке рефлексии в контексте конфликтного взаимодействия партнеров как самим В.А. Лефевром, так и изучавшими рефлексивные процессы другими участниками ММК (Г.П. Щедровицкий, Н.Г. Алексеев, В.В. Давыдов, И.С. Ладенко, В.Е. Лепский, В.М. Розин, И.Н. Семенов, А.А. Тюков и др.). Эти рационалистические представления оказали конструктивное воздействие на психолого-педагогическое изучение рефлексии и на ее сугубо интеллектуалистскую трактовку как осознанности средств и способов мыследеятельности, характерную не только для адептов MMK (О.С. Анисимов, О.И. Генисаретский, В.Я. Дубровский, П.Г. Щедровицкий с их рафинированным проектно-деятельностным подходом, реализовавшимся в прикладном 
плане в социотехнической установке), но и для близких к ММК психологов (В.В. Давыдов, В.П. Зинченко, Н.И. Непомнящая, И.Н. Семенов, В.И. Слободчиков).

Необходимо отметить, что под влиянием интереса к рефлексии в MMK в 1970-е гг. приступает к ее психолого-педагогическому изучению научная школа В.В. Давыдова (А.З. Зак, А.В. Захарова, М.Э. Боцманова, В.В. Рубцов, А.М. Медведев, Г.И. Катрич-Давыдова, П.Г. Нежнов и др.). При этом рефлексия трактуется сугубо рационалистически как интеллектуальная рефлексия, которая вслед за Н.Г. Алексеевым начинает экспериментально исследоваться в школе В.В. Давыдова на материале понятийного и репродуктивного мышления в процессе формирования способов решения типовых учебных задач (см.: Шедровицкий и др., 1993; Семенов, 2014, с. 204-214). Нас интересовала эвристическая роль рефлексии в процессе проблемного и продуктивного мышления, и мы приступили к теоретико-экспериментальному изучению рефлексивных процессов на материале дискурсивного решения творческих задач (Семенов, 1990; Семенов и др., 1977; Semenov, 1978) в контексте психолого-педагогического подхода П.Я. Гальперина к формированию продуктивного мышления и его нормативного анализа средствами системодеятельностной методологии (Щедровицкий и др., 1993; см. также: Семенов, 2014). При этом нами стала разрабатываться гуманитарно-культурологическая парадигма - в оппозиции к социотехнической трактовке рефлексии (В.А. Лефевр, Г.Л. Смолян), а также к нормативно- деятельностному (Н.Г. Алексеев, Г.П. Щедровицкий) и к диалектикодеятельностному (В.В. Давыдов, Э.В. Ильенков) подходам в психологическом изучении рефлексивных процессов. При консультации Н.Г. Алексеева нами была разработана средствами системодеятельностной методологии (см.: Семенов, 2014) концептуальная структурноуровневая модель творческого мышления как системы с рефлексией. Эта модель была верифицирована методом категориально-нормативного анализа на материале теоретико-экспериментального исследования дискурсивного решения творческих задач, что вызвало интерес в США (Semenov, 1978; Холмогорова и др., 1981; Kholmogorova et al., 1982; Кларин, Семенов, 1994), Германии (Matthäus, 1988) и в других странах.

Важно отметить, что идеи и методы В.А. Лефевра оказывали существенное влияние на отечественные исследования рефлексии не только в «советский», но и в «американский» период его творчества, ибо труды В.А. Лефевра по рефлексии развивались его учениками и последователями (В.Е. Лепский, Г.Л. Смолян, П.В. Баранов, В.П. Горяинов, Б.В. Сазонов и др.), издавались не только в американской, но и в российской печати. Более того, они получали высокую оценку и дальнейшее развитие в научно-философских сборниках и в гуманитарных журналах «Вопросы психологии», «Мир психологии», «Вопросы философии», «Психология. Журнал Высшей школы экономики» в статьях Н.Г. Алексеева, О.С. Анисимова, В.Е. Велихова, В.П. Зинченко, И.С. Ладенко, В.А. Лекторского, В.Е. Лепского, В.А. Пет- 
ровского, В.Н. Пушкина, В.М. Розина, М.А. Розова, В.Н. Садовского, И.Н. Семенова, Ю.А. Шрейдера и др. Так, например, предложенный В.А. Лефевром для психологии метод измерения рефлексии (Лефевр, 1971) способствовал разработке нами с коллегами (Ссорин и др., 1985) способов расчета на ЭВМ показателей рефлексивности дискурсивного мышления.

Разрабатывая во ВНИИ технической эстетики (с Н.Г. Алексеевым, В.П. Зинченко, В.М. Муниповым, Э.Г. Юдиным) в середине 1970-х гг. проблематику методологических ориентаций в современной фундаментальной науке и прикладной эргономике (см.: Семенов, 2014, c. 146-182), я окончательно утвердился в своей профессиональной позиции, сводившейся к необходимости создания именно гуманитарно-культурологического варианта рефлексивной психологии. Ее естественно-научный вариант был уже создан в виде логико-кибернетической «Рефлексивной психологии Владимира Лефевра» (Wheeler, 1990), а социотехнический - в трудах ММК (Лефевр и др., 1965; Щедровицкий и др., 1993). Необходимо было перейти к построению гуманитарно-культурологического варианта рефлексивной психологии как наименее разработанной в современной науке, но весьма актуальной для социальной практики рефлексивного управления в менеджменте и гуманизации в образовании (Semyonov, 2002). В итоге удалось экспериментально дифференцировать рефлексию на такие ее виды, как: интеллектуальная, личностная, диалогическая, коммуникативная, кооперативная, экзистенциальная, культуральная, духовная рефлексия (Семенов, 1990, 2012). С учетом этой дифференциации рефлексивных процессов нами были разработаны эффективные психолого-акмеологические рефлетехнологии игрорефлексики как способы развития творческого потенциала и рефлексивных способностей учащихся и взрослых профессионалов в сфере образования, госслужбы и управления (Семенов, Болдина, 2011). Необходимо с благодарностью подчеркнуть, что в этих теоретико-экспериментальных изысканиях и праксиолого-технологических разработках методологическим камертоном изначально являлись фундаментальные исследования В.А. Лефевра по естественно-научному изучению рефлексии и разработке логикокибернетических, инженерно-психологических социотехнических технологий рефлексивного управления. С учетом его постнеклассических трудов по рефлексии, а также достижений классической психологии продуктивного мышления, эргономики проектирования деятельности, акмеологии развития профессионального мастерства и персонологии формирования креативных личностей осуществлялось становление в российском человекознании организационнорефлексивной психологии творчества (Алексеев и др., 1996; Лаптева и др., 2010; Пономарев и др., 1988; Семенов, 1990; Семенов и др., 1977; Semenov, 1978). 


\section{Научно-философское и институциональное значение трудов В.А. Лефевра}

Институализация в России фундаментальных идей и прикладных разработок В.А. Лефевра ведется в трех взаимодополняющих научноорганизационных направлениях: неформальном, полуформальном и формальном. Неформальными являются исторически более ранние (чем формальные институции) методологические кружки (типа ММК, руководимого Г.П. и П.Г. Щедровицкими), работа которых привела к формированию системодеятельностной методологии (см.: Семенов, 2014), исследовательские семинары (типа созданного В.А. Лефевром в ЦЭМИ), итогом которых стала «Рефлексивная психология Владимира Лефевра» (Lefebvre, 1990 - см.: Wheeler, 1990; Lefebvre, 2006), дискуссионные клубы (вроде организованного В.Е. Лепским междисциплинарного «Клуба» в ИФ РАН), обеспечивающие материалы для журнала «Рефлексивные процессы и управление», а также исследовательские институции при научно-общественных академиях (типа созданного нами «Института рефлексивной психологии и педагогики творчества» при «Международной академии гуманизации образования»), которые способствовали формированию научной школы постнеклассической рефлексивной психологии, персонологии, акмеологии и педагогики творчества (Семенов, 2012). В этих институциях с учетом достижений российских научных школ (см.: Семенов, 2009) - Н.Г. Алексеева, O.С. Анисимова, В.В. Давыдова,
В.П. Зинченко, В.Е. Лепского, В.А. Лефевра, В.А. Петровского, И.Н. Семенова, В.Д. Шадрикова, Г.П. Щедровицкого и др. - изучается ныне актуальная проблематика рефлексии (Semenov, 2013) в сфере методологии, социологии, культурологии, психологии, акмеологии, персонологии, политологии, педагогики, системотехники, а также в междисциплинарных исследованиях и практико-ориентированных разработках.

Полуформальные институции это секции при Философском и Психологическом обществах и Научно-проблемные советы на базе исследовательских институтов РАН и РАО. Так, анализ рефлексии в контексте человекознания интенсивно велся в 1970-1990-е гг. на Всесоюзной секции «Психология творчества» (Пономарев и др., 1988) Общества психологов СССР (председатель - Я.А. Пономарев, его заместители - Н.Г. Алексеев, И.Н. Семенов), а в педагогическом контексте в 1990-е гг. на Научном совете по философии образования (Алексеев и др., 1996) при Президиуме РАО (председатель - Н.Г. Алексеев, заместители - И.Н. Семенов, С.Я. Турбовской).

К формальным относятся такие институции в государственных учреждениях, как проблемные группы и лаборатории на университетских и академических кафедрах в вузах. Так, в 2002 г. в госуниверситете «Высшая школа экономики» нами с С.Ю. Степановым была создана кафедра организационной и рефлексивной психологии, что интенсифицировало развитие рефлексивноорганизационной психологии в России (Семенов, 2009; Лаптева и 
др., 2010). Развивая идеи В.А. Лефевра по изучению рефлексии, его соратник В.Е. Лепский в 2016 г. создал на базе Института философии РАН «Центр междисциплинарных исследований рефлексивных процессов и управления» в целях интенсификации и координации в России и за рубежом научных исследований и прикладных разработок социотехнической и социогуманитарной проблематики системного анализа и управления. В этом центре состоялось заседание «Клуба» Института философии РАН, где обсуждались фундаментальные достижения В.А. Лефевра в связи с его 80-летием. Различные аспекты междисциплинарного изучения рефлексии обобщили ученые из РАН, РАНХиГС, МГУ, НИУ ВШЭ и ряда вузов: О.С. Анисимов, В.И. Аршинов, П.В. Баранов, Ю.М. Батурин, В.Е. Лепский, С. Ю. Малков, В.М. Розин, В.А. Петровский, И.Н. Семенов и др.

В связи с историко-научным и философско-методологическим обоснованием исследований рефлексивных процессов важно подчеркнуть фундаментальность разработки В.А. Лефевром междисциплинарной проблематики рефлексии. Ибо еще И. Кант, исходя из методологической критики естествознания, упрекал в ненаучности современную ему эмпирическую психологию, восходящую к эмпиризму Дж. Локка в трактовке рефлексии как внутреннего опыта самонаблюдения души за своими собственными состояниями (см.: Семенов, 2015). Согласно Канту, психология не в состоянии была в то время четко определить изучаемые ею психические объекты, а главное - не могла их измерять и применять математику для экспериментального исследования. В этом контексте следует подчеркнуть конструктивное значение фундаментальных трудов B.А. Лефевра по естественно-научной трактовке рефлексии. Ибо это обеспечило новаторскую постановку и конструктивное решение проблемы измерения рефлексии как важнейшей интегративно-регулятивной грани психической реальности

Небезынтересно заметить, что последние труды крупнейшего эпистемиолога и психолога XX в. Жана Пиаже (Piaget, 1977) были посвящены логико-психологическим исследованиям рефлексии и ее роли в интеллектуальных и нравственных суждениях, он затрагивал проблематику ее категоризации и квантификации. Необходимо подчеркнуть, что еще в «советский» период В.А. Лефевр и его научная школа (Лефевр, 1965, 1971, 1973; Лефевр и др., 1969; Лефевр, Смолян, 1968) раньше начали изучение данной проблемы и дальше пошли в этом направлении, творчески разработав специальный логико-математический аппарат операционализации научного исследования рефлексивных процессов средствами алгебры логики рефлексивных игр. Это открыло конструктивные возможности для развертывания В.А. Лефевром уже в «американский» период не только фундаментальных (Lefebvre, 1982), но и прикладных (Wheeler, 1990) исследований рефлексивных процессов в рамках социотехнической парадигмы практического освоения их естественно-научных закономерностей для оптимизации современного управления в сфере науки, образования, 
экономики, политики, права и решения этических задач современного бытия (Лефевр, 1994). Так, например, в «трансатлантический» Период В.А. Лефевр обобщил значение результатов изучения рефлексии с позиций «алгебры логики и совести» - для современного образования во «Вступительном слове» к «Учебному пособию для старших классов обшеобразовательных и профильных школ» (Омск: ОГИС, 2006). С учетом этого нами разрабатывается рефлексивно-психологическое обеспечение инновационного образования (Алексеев и др., 1996; Семенов, Болдина, 2011).

Параллельно всему этому и особенно в «трансатлантический» период В.А. Лефевр инициирует творческие контакты между российскими и американскими учеными, изучающими рефлексивные процессы в сфере философии, психологии, математики, системного анализа, истории естествознания и техники по философско-методологическому, научно-психологическому и экономико-математическому изучению рефлексивных процессов и их праксиолого-технологическому освое- нию в сфере управления, образования, политики. В это непростое для России переходное время систематически издаются материалы этих конференций и Международный научно-практический междисциплинарный журнал «Рефлексивные процессы и управление» (гл. редактор В.Е. Лепский, члены редколлегии: В.А. Лефевр, академики РАН В.А. Лекторский, В.С. Степин и ученые ряда стран, в том числе профессора НИУ ВШЭ: В.П. Зинченко, В.А. Петровский, А.Н. Поддьяков, И.Н. Семенов), который выходит на русском и английском языках с 2001 г. Таким образом, В.А. Лефевр и его научная школа осуществили не только концептуализацию и операционализацию рефлексии, но и институциализацию системно-междисциплинарных исследований рефлексивных процессов средствами конструктивно взаимодействующих естественных и социальных наук (в том числе рефлексивной: логики, физики, космологии, психологии, социологии, экономики, кибернетики, менеджмента) и социализацию их достижений в современной общественной практике и шире в цивилизационной культуре.

\section{Литература}

Алексеев, Н. Г., Ладенко, И. С., Семенов, И. Н. (1996). мысли о мыслях. Новосибирск: НИИПК. Кларин, М. В., Семенов, И. Н. (ред.). (1994). Гуманистические тенденици в развитии непрерывного образования взрослых в России и СШАА. М.: ИТПИМИО.

Лаптева, О. И., Семенов, И. Н., Куликова, С. Г. (2010). Рефлексивио-организациониая психология. уиебно-методииеское пособие. Новосибирск: НГАА.

Лефевр, В. А. (1963). О различии «процесса решения» и «способа решения» задач. В кн. Тезисы докладов на ІІ съезде Обцества психологов СССР. М.: АПН РСФСР.

Лефевр, В. А. (1965). Исходные идеи логики рефлексивных игр. В кн. Материаль конферениии «Проблемы исследования систем и структур» (с. 73-79). М.: Изд-во АН СССР. 
Лефевр, В. А. (1969). Системы, сравнимые с исследователями по совершенству. В кн. Системные исследования. Ежегодиик-1969 (с. 104-110). М.: Наука.

Лефевр, В. А. (1971). Формальный метод исследования рефлексивных процессов. Вопросы философии, 9, 103-115.

Лефевр, В. А. (1973). Конфликтуюиие структуры (2-е изд.). М.: Советское радио.

Лефевр, В. А. (1990). Непостижимая эффективность математики в исследовании рефлексии. Вотросы философии, 7, 51-59.

Лефевр, В. А. (1991). Формула человека: Контуры фуидаментальной психологии. М.: Прогресс.

Лефевр, В. А. (1994). От репрезентации реальности к репрезентации свободной воли. Психологический журнал, 15(2), 99-121.

Лефевр, В. А. (2003а). Алгебра совести. М.: Когито-Центр.

Лефевр, В. А. (2003б). Рефлексия. М.: Когито-Центр.

Лефевр, В. А. (2005). Космический субъект (3-е изд.). М.: Когито-Центр.

Лефевр, В. А. (2009). Лекции по теории рефлексивных иер. М.: Когито-Центр.

Лефевр, В. А., Лепский, В. Е., Баранов, П. В., Трудолюбов, А. Ф. (1969). Исследование рефлексивных процессов. В кн. В. Н. Пушкин, Д. А. Поспелов, В. Н. Садовский (ред.), Проблемы эвристики (с. 243-270). М.: Советское радио.

Лефевр, В. А., Лепский, В. Е., Петровский, В. А., Семенов, И. Н. (2009). Рефлексивный подход: от методологии к практике. М.: ИФ РАН.

Лефевр, В. А., Смолян, Г. Л. (1968). Алгебра конфликта. М.: Знание.

Лефевр, В. А., Щедровицкий, Г. П., Юдин, Э. Г. (1965). «Естественное» и «искусственное» в семиотических системах. В кн. Материаль конференци «Проблемы исследования систем и структур» (с. 141-149). М.: Изд-во АН СССР.

Петровский, В. А. (2001). Опыт событийной транскрипци рефлексии. Рефлексивные процессы и улравление, $1(1), 61-73$.

Петровский, В. А. (2013). Космизм рефлексии Лефевра. Беседа с В.А. Лефевром. Психология. Журнал Высией иколь экономики, 10(2), 7-23.

Пономарев, Я. А., Семенов, И. Н., Степанов, С. Ю. (ред.) (1988). Психолого-педагоицеские аспекты развития твориества и рефлексии. Материалы научно-практической конференции. М.: Философское общество.

Семенов, И. Н. (1990). Проблемы рефлексивной психологии решетия твориеских задаи. М.: НИИОПП.

Семенов, И. Н. (2009). Обзор отечественных научных школ психологии творчества и рефлексии. Психология. Журиал Высшей иколы экономики, 6(4), 117-123.

Семенов, И. Н. (2012). Методологические проблемы и средства развития постнеклассической психологии рефлексии. Рефлексивные процессы и управление, 13(1-2), 97-100.

Семенов, И. Н. (2014). Системодеятельностная методология и рефлексивная психология мыиления: монография. М.: Институт развития им. Г. П. Щедровицкого.

Семенов, И. Н. (2015). Рефлексивность самонаблюдения и персонология интроспекции: к онтологии и методологии рефлексивной психологии индивидуальности. Вестник Московского упиверситета. Серия 14. Психология, 4, 98-113.

Семенов, И. Н. (2016). Науковедческая рефлексия творчества Б.М. Теплова. Мир психологии, 3(87), 284-296.

Семенов, И. Н., Болдина, Т. Г. (2011). Проектно-исследовательский подход в рефлексивной психологии инновационного образования. Ногинск: Аналитика Родис. 
Семенов, И. Н., Сиротина, Е. А., Зарецкий, В. К. (1977). Исследование рефлексивного аспекта принятия решения как фактора оптимизации мышления. В кн. В. П. Зинченко (ред.), Исследование процессов принятия решения. Эргономика (вып. 14, с. 110-133). М.: ВНИИТЭ.

Ссорин, Ю. А., Семенов, И. Н., Степанов, С. Ю. (1985). Расчет структурных характеристик дискурсивного мышления в решении творческих задач. Алгоритмы и программы. Ннформационный бюллетень: Материаль государственного фонда алгоритмов и программ СССР , 69(6), 39-40.

Теплов, Б. М. (1947). Психология музыкальных способиостей. М.: Учпедгиз.

Холмогорова, А. Б., Зарецкий, В. К., Семенов, И. Н. (1981). Рефлексивно-личностная регуляция целеобразования в норме и патологии. Вестиик Московского университета. Серия 14. Психология, 14(3), 9-21.

Шедровицкий, Г. П., Алексеев, Н. Г., Розин, В. М. (1993). Педагогика и логика. М.: Касталь.

Ссылки на зарубежные истоиники см. в разделе References после англоязыиного блока.

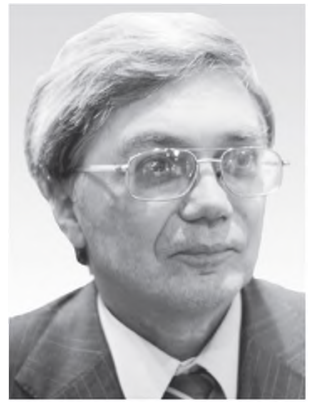

Семенов Игорь Никитович - профессор, Национальный исследовательский университет «Высшая школа экономики», главный редактор журнала «Психология. Историко-критические обзоры и современные исследования», доктор психологических наук, профессор, академик Российской академии естествознания, лауреат Премии Президента РФ в области образования.

Сфера научных интересов: методология и история человекознания, психология мышления и рефлексии, персонология творчества, акмеология управления, гуманизация инновационного образования, педагогика формирования человеческого капитала.

Контакты: i_samenov@mail.ru

\title{
Polyphonic Personology of V.A. Lefebvre and Fundamental Development of Reflexive Sciences of Man and Universe
}

\author{
I.N. Semenov \\ ${ }^{a}$ National Research University Higher School of Economics, 20 Myasnitskaya Str., Moscore, 101000, \\ Russian Federation
}

\begin{abstract}
One of the fundamental achievements of the science of man at the turn of the XX-XXI centuries is the "Reflexional psychology of Vladimir Lefebvre" (Wheeler, 1990). It is the result of interdisciplinary synthesis of an array of the emerged in the XXth century reflexional sciences: logics, semiotics, psychology, conflictology, ethics, management, politology, systems science, cybernetics, physics, mathematics, cosmology. The Russian-American scientist V.A. Lefebvre
\end{abstract}


contributed to each of them. V.A. Lefebvre has the Renaissant range of research interests, phenomenal creativity, encyclopeadism of professional activity. The research objective of this article is the analysis of V.A. Lefebvre's trajectory of life and his creative achievements in the field of interdisciplinary studies of such complex psychological reality as reflexivity. For the first time the personological periodization of V.A. Lefebvre's life was suggested, the development of his personality in three key periods of his work (Soviet, American, Transatlantic) was characterized, the analysis of his scientific achievements was conducted. The constructivity of V.A. Lefebvre's systematic interdisciplinary approach to the study and learning of reflexive processes in the context of the modern development of science and society is shown. The novelty of the results from the study of V.A. Lefebvre's creative life is determined by the systematic methodology of his reflexive-scientific studies according to the complementarity principle. This principle is realized by means of interaction of personological approach to characteristics of V.A. Lefebvre's creative personality and scientific approach to the analysis of his innovative scientific work in the contemporary sociocultural context of development of science and society. In the end, the fundamental significance of V.A. Lefebvre's interdisciplinary works for the study of reflexion on a scale of science of man and cosmology is shown.

Keywords: philosophy, sociology of science, methodology, logics, system, personology, psychology, conflictology, ethics, cosmology, reflexion, activity, management, creativity.

\section{References}

Alekseev, N. G., Ladenko, I. S., \& Semenov, I. N. (1996). Mysli o myslyakh [Thoughts on thoughts]. Novosibirsk: NIIPK.

Kholmogorova, A. B., Zaretskii, V. K., \& Semenov, I. N. (1982). Reflexive-personal regulation of normal and pathological goal formation. Soviet Psychology, 20(4), 79-97.

Klarin, M. V., \& Semenov, I. N. (Eds.). (1994). Gumanisticheskie tendentsii v razvitii nepreryonogo obrazovaniya vzroslykh $v$ Rossii iSShA [Humanistic tendencies in development of continuous education of adults in Russia and the USA]. Moscow: ITPIMIO.

Lapteva, O. I., Semenov, I. N., \& Kulikova, S. G. (2010). Refleksivno-organizatsionnaya psikhologiya [The reflexional-organizational psychology]. Novosibirsk: NGAA.

Lefebvre, V. A. (2006). Research on bipolarity and reflexivity. Lewiston: The Edwin Mellen Press.

Lefebvre, V. A. (1982). Algebra of conscience. Boston, MA: Reidel.

Lefebvre, V. A. (1990). The stnucture of human reflexion. In Wheeler, H. (Ed.). The structure of human reflexion: the reflexional psychology of Vladimir Lefebvre. New York: Lang.

Lefebvre, V. A. (1963). O razlichii "protsessa resheniya" i "sposoba resheniya" zadach [On the difference between the "process of problem-solving" and the "way of problem solving"]. In Tezisy dokladov na II s"ezde Obshchestra psikhologov SSSR [Proceedings of the II Congress of the USSR Psychological Society]. Moscow: APN RSFSR.

Lefebvre, V. A. (1965). Iskhodnye idei logiki refleksivnykh igr [The root ideas of the logics of reflexional games]. In Materialy konferentsii "Problemy issledovaniya sistem i struktur" [Proceedings of the conference "Issues of the research on systems and structures"] (pp. 73-79). Moscow: AN SSSR. 
Lefebvre, V. A. (1969). Sistemy, sravnimye s issledovatelyami po sovershenstvu [Systems, comparable to researchers in their sophistication]. In Sistemnye issledovaniya. Ezhegodnik-1969 [System studies. Yearbook 1969] (pp. 104-110). Moscow: Nauka.

Lefebvre, V. A. (1971). Formal'nyi metod issledovaniya refleksivnykh protsessov [Formal method of study of the reflexional processes]. Voprosy Filosofii, 9, 103-115.

Lefebvre, V. A. (1973). Konfliktuyushchie struktury [Conflicting structures] (2nd ed.). Moscow: Sovetskoe Radio.

Lefebvre, V. A. (1990). Nepostizhimaya effektivnost' matematiki v issledovanii refleksii [Inconceivable effectiveness of mathematics in the study of reflexion]. Voprosy Filosofii, 7, 51-59.

Lefebvre, V. A. (1991). Formula cheloveka: Kontury fundamental'noi psikhologii [The formula of man: Shapes of fundamental psychology]. Moscow: Progress.

Lefebvre, V. A. (1994). Ot reprezentatsii real'nosti k reprezentatsii svobodnoi voli [From representation of reality to representation of free will]. Psikhologicheskii Zhumal, 15(2), 99-121.

Lefebvre, V. A. (2003a). Algebra sovesti [Algebra of conscience]. Moscow: Kogito-Tsentr.

Lefebvre, V. A. (2003b). Refleksiya [Reflexion]. Moscow: Kogito-Tsentr.

Lefebvre, V. A. (2005). Kosmicheskii sub"ekt [The cosmic subject] (3rd ed.). Moscow: Kogito-Tsentr.

Lefebvre, V. A. (2009). Lektsii po teorii refleksirmykh igr [Lections on the theory of reflexional games]. Moscow: Kogito-Tsentr.

Lefebvre, V. A., \& Smolyan, G. L. (1968). Algebra konflikta [The algebra of conflict]. Moscow: Znanie.

Lefebvre, V. A., Lepsky, V. E., Baranov, P. V., \& Trudolubov, A. F. (1969). Issledovanie refleksivnykh protsessov [The study of reflexional processes]. In V. N. Pushkin, D. A. Pospelov, V. N. Sadovskii (Eds.), Problemy evristiki [Issues of heuristics] (pp. 243-270). Moscow: Sovetskoe Radio.

Lefebvre, V. A., Lepsky, V. E., Petrovsky, V. A., \& Semenov, I. N. (2009). Refleksirmyi podkhod: ot metodologii $k$ praktike [The reflexional approach: From methodology to practice]. Moscow: IF RAN.

Lefebvre, V. A., Shchedrovitskii, G. P., \& Yudin, E. G. (1965). "Estestvennoe" i "iskusstvennoe" v semioticheskikh sistemakh ["Natural" and "artificial" in the semiotic systems]. In Materialy konferentsii "Problemy issledovaniya sistem i struktur" [Proceedings of the conference "Issues of the research on systems and structures"] (pp. 141-149). Moscow: AN SSSR.

Matthäus, W. (1988). Sorejetische Denkpsychologie. Göttingen: Hogrefe.

Petrovsky, V. A. (2001). Opyt sobytiinoi transkriptsii refleksii [An attempt of event-related transcription of reflexion]. Reflexive Processes and Control. Intemational Interdisciplinary Scientific and Practical Journal, 1(1), 61-73.

Petrovsky, V. A. (2013). The cosmism of Lefebvre's reflection. Interview with V.A. Lefebvre. Psychology. Joumal of Higher School of Economics, 10(2), 7-23. (in Russian)

Piaget, J. (1977). Recherches sur l'abstraction réfléchissante. Paris: PUF. (in French)

Ponomarev, Ya. A., Semenov, I. N., \& Stepanov, S. Yu. (1988). Psikhologo-pedagogicheskie aspekty razoitiya tvorchestva i refleksii [Psychological pedagogical aspects of development of creativity and reflexion]. Moscow: Filosofskoe Obshchestvo.

Semenov, I. N. (1978). An empirical psychological study of though processes in creative problem-solving from the perspective of the theory of activity. Soviet Psychology, 16(4), 3-46.

Semenov, I. N. (1990). Problemy refleksionoi psikhologii resheniya toorcheskikh zadach [Issues of reflexional psychology of creative problem-solving]. Moscow: NIIOPP.

Semenov I. N. (2009). An overview of scientific schools of Russian psychology of creativity and selfreflection. The Psychology. Joumal of Higher School of Economics, 6(4), 117-123. (in Russian) 
Semenov, I. N. (2012). Metodologicheskie problemy i sredstva razvitiya postneklassicheskoi psikhologii refleksii [Methodological issues and means of development of post-non-classical psychology of reflexion]. Reflexive Processes and Control. International Interdisciplinary Scientific and Practical Journal, 13(1-2), 97-100.

Semenov, I. N. (2013). Milestones and logic of formation of reflexive psyccology at then of XX-XXI centuries. Psikhologiya. Istoriko-kriticheskie Obzony i Sovremennye Issledovaniya, 2(3-4), 52-75.

Semenov, I. N. (2014). Sistemodeyatel'nostnaya metodologiya i refleksivnaya psikhologiya myshleniya [System-activity methodology and reflexional psychology of thinking]. Moscow: Institut razvitiya im. G. P. Shchedrovitskogo.

Semenov, I. N. (2015). The reflexivity of self-observation and personology of introspection: To ontology and methodology of reflexive psychology of personality (the end). Vestnik Moskovskogo Universiteta. Seriya 14. Psikhologiya, 4, 9-113. (in Russian)

Semenov, I. N. (2016). Scientific reflection of B. M. Teplov's creativity. World of Psychology, 3(87), $284-296$.

Semenov, I. N., \& Boldina, T. G. (2011). Proektno-issledovatel'skii podkhod v refleksirnoi psikhologii innovatsionnogo obrazovaniya [Project-study approach in reflexional psychology of innovative education]. Noginsk: Analitika Rodis.

Semenov, I. N., Sirotina, E. A., \& Zaretskii, V. K. (1977). Issledovanie refleksivnogo aspekta prinyatiya resheniya kak faktora optimizatsii myshleniya [The study of reflexional aspect of decision-making as a factor of optimization of thinking]. In V. P. Zinchenko (Ed.), Issledovanie protsessov primyatiya resheniya. Ergonomika [Study of the process of decision-making] (Iss. 14, pp. 110-133). Moscow: VNIITE.

Semyonov, I. N. (2002). Philosophy of humanization of education and reflexiveness of dialogue. Reflexive Processes and Control. International Interdisciplinary Scientific and Practical Joumal, 1(1), 95-101.

Shchedrovitskii, G. P., Alekseev, N. G., \& Rozin, V. M. (1993). Pedagogika i logika [Pedagogy and logics]. Moscow: Kastal'.

Ssorin, Yu. A., Semenov, I. N., \& Stepanov, S. Yu. (1985). Raschet strukturnykh kharakteristik diskursivnogo myshleniya $\mathrm{v}$ reshenii tvorcheskikh zadach [Estimation of structural characteristics of discursive thinking in creative problem-solving]. Algoritmy i Programmy. Informatsionmyi Byulleten': Materialy Gosudarstvennogo Fonda Algoritmov i Programm, 69(6), 39-40.

Teplov, B. M. (1947). Psikhologiya muzykal'nykh sposobnostei. Moscow: Uchpedgiz.

Wheeler, H. (Ed.). (1990). The structure of human reflexion: the reflexional psychology of Vladimir Lefebvre. New York: Lang.

Igor N. Semenov - professor, National Research University Higher School of Economics, D.Sc. Research area: methodology and history of the science of man, psychology of thinking and reflection, personology of creativity, acmeology of management, humanization of innovational education, pedagogy of formation of human capital.

E-mail: i samenov@mail.ru 